\title{
Research on Practical Mode of Ideological and Political Education on Colleges
}

\author{
Wenxiao Yang \\ Anyang Normal University, Anyang, Henan, 455001
}

Keywords: Practical Mode, Ideological and Political Education, College Management

\begin{abstract}
The improvement of people's ideological and moral qualities is a complicated process, which is a coordinated development of knowledge and intention. Among them, "line" is the key. However, the current ideological and political education in colleges universally exists the problem of lack of practice and education, the separation of college students' theory and practice and the disconnection between knowledge and practice, which have greatly affected the actual ideological and political education. Based on the law of the growth of talents and the formation of the ideological and moral qualities of college students, this paper focuses on the formation of laws and uses the methods of text interpretation, investigation and comparative analysis, and takes practice as the research object, elaborates the limitations and drawbacks in relatively closed and one-sided infusion of ideological and political education model.
\end{abstract}

\section{Introduction}

The course of ideological and political theory is the "main channel" for college students to conduct systematic ideological and political education, which has always been highly valued by the party and the state. As a required course for college students, it is an important way to help college students to establish a correct world outlook, outlook on life and values, which embodies the essential requirements of a socialist university. For a long time, it has played an irreplaceable role in strengthening the political orientation of college students and improving their ideological and moral qualities. However, with the increasingly technical and professional nature of modern higher education, the idea of educating people in universities gradually becomes biased. Higher education falls into a "dehumanized" position, ignoring the status of ideological and political education in personnel training, Political education is limited to class theory teaching, there is a lot of phenomena that neglect the role of practice and education, and heavy theory and light practice have become an important factor that affects the effect of ideological and political education in colleges. Coupled with the subject and object of the opposite way of thinking and the "intellectual moral education" influence, so that ideological and political education in colleges to a certain extent become educators training and control of educated people, in this framework of education mode, the main body of students Sex can easily be neglected, and ideological and political education can easily become a rigid inculcation of hollow political theory and moral concepts. As a result, the disjunction between the theory and practice of students and the division of moral cognition and moral behavior are caused. Nowadays, some college students have varying degrees of political confusion, vague ideals and beliefs, distorted values, weak sense of integrity, lack of social responsibility, weakness in hard work, poor unity and cooperation, and poor psychological quality. The author believes that the causes of such a result are many, including the traditional ideological and political education mode because of the practice of education is weak and the factors that affect the effectiveness of education can not be avoided.

\section{New Requirements for Ideological and Political Education in Higher Education}

The concept of globalization was first put forward by economist Levi in his article entitled "Market globalization" in the year, referring to the great changes that took place in the international economy in the previous year, namely the global nature of goods, services, capital and technology Production, consumption and investment in the area of proliferation. Economic globalization means 
that all countries, regions and groups of countries, under the impetus of the ever-developing scientific and technological revolution and the internationalization of production, are all interdependent and interdependent with each other. Both the economic sector and the economic environment have become an integral part of this whole. It is an objective requirement for the development of productive forces around the world and is the result of the promotion of new scientific and technological revolution after World War II. It is an objective trend that does not depend on the will of the people. After World War II, the revolution in science and technology greatly increased labor productivity, deepened the internationalization of all countries, promoted the development of world trade, strengthened the interdependence of the economies in various countries, led to the establishment and expansion of regional economic groups and accelerated the development of the world economic globalization. As we enter the new century, the development of globalization has further deepened. The flow and allocation of resources around the world have made the interdependence between nations an unprecedented breadth and depth.

No matter how the education reform, the use of classroom teaching for ideological and political education has always been the most basic way, because classroom teaching is, after all, the most important factor in the education process. However, since ideology and morality belong to the spiritual field activities of human beings, it is necessary for some people to participate in the emotional experience in order to achieve the desired goal. Therefore, focusing on the classroom can not be equated with one-sided instillation. Western scholars believe that the use of classroom teaching to teach students some specific, practical, relatively stable moral rules and values advocated by the state is valid. From the perspective of curricula, all countries in the West have given lectures according to the aims, contents and systems of ideological and moral education in schools at all levels in the country and the region. Although they are called different schools, they are usually taught as regular courses. From the perspective of pluralistic democratic values, the United States has long implemented the "buffet-style curriculum" without the uniform standards of the state. In the late -1990s, the number of applied ethics courses in all American universities exceeded the kinds. However, it caused chaos in values and did not achieve the expected results Effect. Therefore, the state education crisis in impending impetus during the year is imperative "and established a basic course that includes high school graduates at least to revise the social sciences. The "American Year of Education Goals Act", which takes effect every year, lists the "Civics and Politics" course on moral education as the core curriculum. This shows that the U.S. government attaches importance to this kind of moral education for adolescents through curriculum teaching. The "Education Reform Act of the United Kingdom" also stipulates ten courses and proposes to set up these ten courses with the purpose of "ensuring the development of students' spirit, morality, culture, intelligence and body, accumulating knowledge and cultivating responsibilities for students". For specialized moral education courses such as "Applied Ethics" and "Moral Reasoning," Western universities generally regard it as a compulsory course for students majoring in various fields and adopt rigid administrative measures to suspend the credits of such courses from their degrees to be provided and guaranteed. In short, in the face of the challenges of the new century, all countries in the world have set up unified courses one after another to strengthen the state's control over education and moral education. This reflects the true intention of competing for talent behind the ideological and moral education for young people in the future.

\section{The Overall Structure of Ideological and Political Education in Colleges}

The so-called principle, refers to under certain conditions, people observe the problem, analyze the problem and the basis of the criteria or guidelines. The guiding principle for the practice and mode of ideological and political education is the basic principle that should be followed in constructing, implementing and implementing the practice and mode of ideological and political education. It reflects the changes in the internal and external environment of higher education. The direction of education reform and development, especially the basic law of ideological and political education, determines and influences the operation process and system construction of practice and education mode. To grasp and follow these basic principles is of great significance in grasping the 
regularity of practicing the mode of educating people, overcoming the subjective blindness, and obtaining the actual effectiveness of educating people.

Establishing a scientific organizational structure can coordinate internal and external coordination through certain mechanisms and concentrate and amplify various individual forces. On the one hand, this coordination mechanism restricts individual behavior through various norms to reduce internal friction and form a common will. On the other hand, the coordination mechanism enables people's behavior to be more in line with the regularity of various activities so as to make the collective forces act just as they are, appropriately play a complex superimposed effect, which greatly exceeds the power of a single person can show. The practice and education model is a challenge to the ideological and political education in traditional universities. It needs the change from concept to practice. Therefore, building a scientific management organization structure in practice and education mode is an important measure to meet this challenge. Organizational structure is the organization of the internal work groups at all levels in the vertical and horizontal settings of various departments and their relationship. It is the framework of the organization system, constitute the basic form of organization.

The Opinions of CPC Central Committee and State Council on Further Strengthening and Improving College Students' Ideological and Political Education requires that we establish a social practice guarantee system for college students, explore and implement a long-term mechanism for educating and educating students, guide college students to go out of school, go to grassroots level, and go among workers and peasants. It is necessary to include social practice in the overall plan and teaching outline of school education and teaching, stipulate the time and credits, set up the organizational guarantee system and funding to promote the normal social practice, and provide the foundation for the continuous implementation of social practice. Not only the social practice of college students referred to the height of practice and education, but also put forward specific requirements for its implementation. From which we can see that the practice of educating people requires not only the change of concept of teachers and students, but also need to establish and improve a scientific and feasible operating mechanism, complete and operable mode of operation, and combine it with the teaching of ideological and political theory. Without a complete scientific and feasible operation mechanism and not incorporating them into the teaching field of vision, the practical activities are blind, fail to bring about the expected gains and can not play their due role in education. Therefore, all departments and colleges in colleges should actively cooperate with each other to integrate practice and education into the overall education and teaching management system of the school, form a model of full-staff education, establish and perfect the management mechanism, guarantee mechanism, reward and punishment mechanism and evaluation mechanism for social practice activities. The long-term and healthy development of social practice lays a solid foundation.

The basic characteristics of the activity-based curriculum, or its fundamental difference with the traditional cognitive theory of ideological and political course is reflected in the following points. First of all, activity classes are practical. In terms of belonging, activity class is a practical course of ideological and political theory course. It is based on practical activities outside the classroom, including all kinds of activities in the campus and all kinds of practical activities outside the campus. Some scholars put forward that can be directly called thought practice class. The setting of this course is a useful attempt to educate the students in colleges. The purpose of this course is not to replace the teaching of ideological and political theory led by classroom instillation, because even active courses still need the necessary inculcation and implicit teaching, only Different from classroom-based classroom teaching, it is conducted in a variety of concrete activity situations, such as the realization of basic principles and basic principles in the process of natural or inadvertent practices such as practical guidance, question discussion, summarization and evaluation Indoctrination of basic values. In contrast, activity classes pay more attention to the integrity of the goal and the overall function of the curriculum. The Soviet educator Skatkin argues that the curriculum structure should establish a "central core" of the social and scientific cultural phenomena and ideas that are most important to human life, making the curriculum a knowledge 
base around this fundamental core. The goal of integrity of the activity class and the overall optimization of the performance of performance In order to make full use of practical teaching resources to ideological and moral qualities, political quality, cultural and scientific quality, aesthetic quality and psychological quality as the core, to achieve cognitive and emotional, intellectual and intellectual, The main body of the spirit of unity and social responsibility.

\section{Conclusions}

How to effectively improve the actual effectiveness of ideological and political education has been a question that the Party and the country as well as the majority of university teachers have been thinking for many years and has continuously conducted exploration and reform in practice. The combination of theory and practice is the basic principle of Marxism as well as the basic principle of education. Adhere to the combination of theory and practice Educating people in line with the laws of education, in line with the formation of the ideological and moral quality of college students, in line with the law of growth and success of college students. Therefore, in the current undergraduates' ideological and political education, there is a common practice of lack of practice or even lack of practice, the construction of practice mode of education, highlighting the practical value of education, effectively improving the effectiveness of ideological and political education due to lack of practice and education to improve or even The realization of the goal and the promotion of the combination of theory and practice to conduct a comprehensive education are the necessary requirements to strengthen and improve the ideological and political education of college students.

\section{References}

[1] Wei Tongyi. On college students ideological and political education and the construction of a harmonious campus [J]. Theory. 2007 (12)

[2] Tang Yaoping. Strengthen college students ideological and political education and building a harmonious campus thinking [J]. Higher Education Exploration. 2007 (06)

[3] Zhang Jijun, Li Shu. Innovative ideological and political education to promote the construction of a harmonious campus [J]. Study Monthly. 2007 (18)

[4] Li Guohui, Yang Fang. On Students Ideological and Political Education and the Construction of a Harmonious Campus [J]. Education of Ideological and Political Education. 2007 (03)

[5] Yang Xueyi. The current understanding of the construction of a harmonious campus and thinking [J]. School Party Building and Ideological Education. 2007 (06)

[6] Wen Diji. College students ideological and political education adhere to the concept of "people-oriented" [J]. School Party Building and Ideological Education. 2007 (06) 